\title{
PERSEPSI PETANI TERHADAP PERAN PENYULUH PERTANIAN DI DESA LADA MANDALA JAYA KECAMATAN PANGKALAN LADA KABUPATEN KOTAWARINGIN BARAT
}

\author{
FARMER PERCEPTION OF THE ROLE OF AGRICULTURE EXTENSION \\ IN LADA MANDALA JAYA VILLAGE, PANGKALAN LADA DISTRICT, \\ KOTAWARINGIN BARAT DISTRICT
}

\author{
${ }^{1}$ M. Amrullah, ${ }^{2}$ Abdul Mukti, ${ }^{3}$ Eka Nor Taufik
}

\author{
${ }^{1}$ Alumnus Program Studi Agribisnis Fakultas Pertanian Universitas Palangka Raya \\ ${ }^{2,3}$ Staf Pengajar Program Studi Agribisnis Fakultas Pertanian Universitas Palangka Raya \\ email: abdulmukti.1201@agb.upr.ac.id
}

\begin{abstract}
ABSTRAK
Penelitian ini bertujuan untuk mengetahui persepsi petani terhadap peran penyuluh pertanian. Peran/tugas penyuluh meliputi edukasi, diseminasi informasi/inovasi, fasilitasi, konsultasi, supervisi, pemantauan dan evaluasi, dimana keenamnya di dalam penelitian ini menjadi variabel penelitian. Skala Likert digunakan untuk mengukur persepsi petani karet terhadap keseluruhan peran penyuluh pertanian dimaksud. Dari hasil penelitian diketahui bahwa persepsi petani untuk peran penyuluh dinilai berada pada kategori "berperan" dengan rerata secara keseluruhan 3,47. Persepsi petani terhadap peran penyuluh pertanian di Desa Lada Mandala Jaya, Kecamatan Pangkalan Lada dapat dikategorikan sebagai (a). "Cukup Berperan" (rerata $=3,15$ ) untuk sub variabel Konsultasi, (b). "Cukup Berperan" (rerata = 2,61) untuk sub variabel Monitoring dan Evaluasi, $(c)$. "Berperan" (rerata $=3,69$ ) untuk sub variabel Edukasi, (d). "Berperan" (rerata $=3,41$ ) untuk sub variabel Diseminasi, $(e)$. "Berperan" (rerata $=3,48$ ) untuk sub variabel Fasilitasi, dan $(\mathrm{f})$. "Berperan" (rerata $=3,41$ ) untuk sub variabel Supervisi. Disarankan kepada penyuluh agar dapat mengoptimalkan peran penyuluh terutama dalam memfasilitasi dan melakukan supervisi kepada petani dalam pembangunan usaha perkebunan karet.
\end{abstract}

Kata kunci: persepsi, peran penyuluh, skala Likert

\section{ABSTRACT}

This study aims to determine the perception of farmers on the role of agricultural extension. Extension roles/duties include education, dissemination of information/innovation, facilitation, consultation, supervision, monitoring and evaluation, where the sixth in this study into research variables. Likert scale is used to measure the perception of rubber farmers to the overall role of agricultural extension workers. From the results of the research note that the perception of farmers for the role of extension workers in the value is in the category "enough to play" with the overall average of 3.11. The perception of farmers on the role of agricultural extension in Lada Mandala Jaya Village, Pangkalan Lada Sub-district can be categorized as (a). "role" (mean = 3,69) for sub-variable of Education, (b). "role" (mean = 3,41) for the sub-variable Dissemination, (c). "lacks role" (average =2.24) as the Facilitator, $(d)$. "enough role" (average $=3.15$ ) as consultant, $(e)$. "enough role" (average $=2.60$ ) as Supervisor, and $(f)$. "enough role" (average $=2.61$ ) in the implementation of Monitoring and Evaluation. It is advisable to extension workers to optimize the role of extension workers, 
especially in facilitating and supervising the farmers in the development of rubber plantation business.

Keywords: Extension role, Likert scale, perception

\section{PENDAHULUAN}

\section{Latar Belakang dan Permasalahan}

Undang-Undang Nomor 16 Tahun 2006 tentang Sistem Penyuluhan Pertanian, Perikanan, dan Kehutanan menyatakan bahwa penyuluhan merupakan suatu upaya atau proses kegiatan yang dilakukan dalam rangka pemberdayaan masyarakat dan petani sebagai proses pembelajaran bagi pelaku utama dan pelaku usaha agar mereka mau dan mampu menolong serta mengorganisasikan dirinya dalam mengakses informasi pasar, teknologi, permodalan, dan sumberdaya lainnya sebagai upaya untuk meningkatkan produktivitas, efisiensi usaha, pendapatan, dan kesejahteraannya, serta meningkatkan kesadaran dalam pelestarian fungsi lingkungan hidup.

Kartasapoetra (1994) menyatakan bahwa penyuluh pertanian adalah agen bagi perubahan perilaku petani, melalui peningkatan pengetahuan, sikap, keterampilan serta motivasi petani sasarannya. Selain itu juga untuk mendorong petani mengubah perilakunya menjadi petani dengan kemampuan yang lebih baik dan mampu mengambil keputusan sendiri, yang selanjutnya akan memperoleh kehidupan yang lebih baik. Melalui peran penyuluh, petani diharapkan menyadari akan kebutuhannya, melakukan peningkatan kemampuan diri, dan dapat berperan di masyarakat dengan lebih baik.

Menurut Samsudin (2012), bahwa tujuan penyuluhan pertanian bukan saja untuk menimbulkan dan mengubah pengetahuan, kecakapan, sikap, danmotivasi petani, tetapi yang lebih penting adalah merubah sifat pasif dan statis menjadi petani aktif dan dinamis. Petani akhirnya mampu berfikir dan berpendapat sendiri untuk mencoba dan melaksanakan sesuatu yang pernah didengar dan dilihatnya. Dipertegaskan berdasarkan rumusan Pasal 3 UndangUndang Nomor 16 Tahun 2006 tentang Sistem Penyuluhan Pertanian, Perikanan, dan Kehutanan (SP3K), maka tujuan penyuluh pertanian adalah sebagai berikut:

1. Memperkuat pengembangan pertanian, perikanan, serta kehutanan yang maju dan modern dalam sistem pembangunan yang berkelanjutan,

2. Memberdayakan pelaku utama dan pelaku usaha dalam peningkatan kemampuan melalui penciptaan iklim usaha yang kondusif, penumbuhan motivasi, pengembangan potensi, pemberian peluang, peningkatan kesadaran, dan pendampingan, serta fasilitasi,

3. Memberikan kepastian hukum bagi terselenggaranya penyuluh yang produktif, efektif, efisien, terdesentralisasi, partisipatif, terbuka, berswadaya, bermitra sejajar, kesetaraan gender, berwawasan luas ke depan, berwawasan lingkungan, dan bertanggung gugat yang dapat menjamin terlaksananya pembangunan pertanian, perikanan, dan kehutanan,

4. Memberikan perlindungan, keadilan, dan kepastian hukum bagi pelaku utama dan pelaku usaha untuk mendapatkan pelayanan penyuluh serta bagi penyuluh dalam melaksanakan penyuluhan.

5. Mengembangkan sumberdaya manusia, yang maju dan sejahtera, sebagai pelaku dan sasaran utama pembangunan pertanian, perikanan dan kehutanan.

Fungsi penyuluh sesuai dengan Pasal 4 Undang-Undang Nomor 16 Tahun 2006 tentang Sistem Penyuluh Pertanian, Perikanan, dan Kehutanan (SP3K) adalah:

1. Memfasilitasi proses pembelajaran pelaku utama dan pelaku usaha;

2. Mengupayakan kemudahan akses pelaku utama dan pelaku usaha ke 
sumber informasi, teknologi, dan sumberdaya lainnya agar dapat mengembangkan usahanya;

3. Meningkatkan kemampuan kepemimpinan, manajerial, dan kewirausahaan pelaku utama dan pelaku usaha;

4. Membantu pelaku utama dan pelaku usaha dalam menumbuhkembangkan organisasinya menjadi organisasi ekonomi yang berdayasaing tinggi, produktif, menerapkan tata kelola berusaha yang baik, danberkelanjutan;

5. Membantu menganalisis dan memecahkan masalah serta merespon peluang dan tantangan yang dihadapi pelaku utama dan pelaku usaha dalam mengelola usaha;

6. Menumbuhkan kesadaran pelaku utama dan pelaku usaha terhadap kelestarian fungsi lingkungan; dan

7. Melembagakan nilai-nilai budaya pembangunan pertanian, perikanan dan kehutanan yang maju dan modern bagi pelaku utama secara berkelanjutan.

Areal tanaman karet di Kecamatan Pangkalan Lada adalah yang terluas di Kabupaten Kotawaringin Barat, sebagaimana rinciannya dapat dilihat pada Tabel 1 berikut ini.

Tabel 1. Luas Areal Tanaman Karet Menurut Kecamatan di Kabupaten Kotawaringin Barat Tahun 2016

\begin{tabular}{clrr}
\hline \multirow{2}{*}{ No. } & \multicolumn{1}{c}{ Kecamatan } & \multicolumn{2}{c}{ Luas Areal } \\
\cline { 3 - 4 } & & Hektar $(\mathrm{Ha})$ & Persentase $(\%)$ \\
\hline 1. & Kotawaringin Lama & 1.207 & 19,76 \\
2. & Arut Selatan & 821 & 13,44 \\
3. & Kumai & 976 & 15,98 \\
4. & Pangkalan Banteng & 417 & 6,83 \\
5. & Pangkalan Lada & 1.964 & 32,15 \\
6. & Arut Utara & 724 & 11,85 \\
\hline & \multicolumn{1}{c}{ Jumlah } & 6.108 & 100,00 \\
\hline
\end{tabular}

Sumber: Dinas Pertanian Tanaman Pangan, Hortikultura dan Perkebunan Kabupaten Kotawaringin Barat, Tahun 2017.

Berdasarkan Tabel 1 di atas, dapat diketahui bahwa areal tanaman karet di Kecamatan Pangkalan Lada adalah seluas 1.964 hektar atau 32,15\% dari luas areal keseluruhan tanaman karet di Kabupaten
Kotawaringin Barat. Sementara luas areal tanaman karet menurut desa di Kecamatan Pangkalan Lada dapat dilihat pada Tabel 2 berikut.

Tabel 2. Luas Areal Tanaman Karet Menurut Desa/Kelurahan di Kecamatan Pangkalan Lada Tahun 2016

\begin{tabular}{clrr}
\hline \multirow{2}{*}{ No. } & \multicolumn{2}{c}{ Desa/Kelurahan } & \multicolumn{2}{c}{ Luas Areal (Ha) } \\
\cline { 3 - 4 } & & 300 & Persentase $(\%)$ \\
\hline 1. & Purbasari & 54 & 15,12 \\
2. & Sungai Rangit Jaya & 151 & 2,72 \\
3. & Sumber Agung & 452 & 7,61 \\
4. & Lada Mandala Jaya & 60 & 22,78 \\
5. & Makarti Jaya & 315 & 3,02 \\
6. & Pandu Senjaya & 102 & 15,88 \\
7. & Pangkalan Tiga & 70 & 5,14 \\
8. & Kedipi Atas & 50 & 3,53 \\
9. & Pangkalan Dewa & 280 & 2,52 \\
10. & Pangkalan Durin & & 14,11
\end{tabular}


11. Sungai Melawen

150

7,56

Jumlah

1.984

100,00

Sumber: Dinas Pertanian Tanaman Pangan, Hortikultura dan Perkebunan Kabupaten Kotawaringin Barat, Tahun 2017.

Berdasarkan Tabel 2 di atas, dapat diketahui bahwa dari sebelas desa yang berada di Kecamatan Pangkalan Lada, maka areal tanaman karet di desa Lada Mandala Jaya yang relatif paling luas (452 Ha) atau lebih kurang $22,78 \%$ dari total luas tanaman karet di Kecamatan Pangkalan Lada.

Ternyata dengan luas areal tanaman karet di Desa Lada Mandala Jaya Kecamatan Pangkalan Lada itu hanya dibina oleh 1 (satu) orang tenaga penyuluh pertanian. Memang, di dalam UndangUndang Nomor 19 Tahun 2013 tentang Perlindungan dan Pemberdayaan Petani disebutkan bahwa paling sedikit terdapat satu orang penyuluh pada setiap desa pertanian.

Akan tetapi, menurut Kepala Badan Ketahanan Pangan dan Koordinasi Penyuluhan Kalimantan Tengah, Sutrisno, mengakui kurangnya tenaga penyuluh pertanian di daerah masih kurang. Padahal kekurangan tenaga penyuluh pertanian ini baru dihitung kalau satu orang tenaga penyuluh pertanian per desa. Apalagi, untuk idealnya tenaga penyuluh pertanian adalah tiga orang dalam per desa, karena pertanian memiliki arti yang luas, mulai dari pertanian tanaman pangan, perikanan, maupun peternakan sehingga pemahaman seseorang penyuluh tidak akan mungkin mampu secara keseluruhan (Antara Kalteng, 2014). Dengan keadaan tersebut maka penelitian mengenai persepsi petani terhadap peran penyuluh pertanian di Desa Lada Mandala Jaya perlu dilakukan untuk mengetahui seberapa besar peran penyuluh pertanian.

\section{Tujuan dan Kegunaan Penelitian}

Berdasarkan permasalahan diatas maka penelitian ini bertujuan untuk mengetahui persepsi petani terhadap peran penyuluh pertanian.Dari hasil penelitian ini diharapkan dapat berguna khususnya bagi penyuluh di Desa Lada Mandala Jaya Kecamatan Pangkalan Lada Kabupaten Kotawaringin Barat dalam memperbaiki perannya.

\section{TINJAUAN PUSTAKA}

\section{Peran Penyuluh dan Persepsi Petani}

Mardikanto (2010), mengemukakan beragam peran/tugas penyuluh dalam satu kata yaitu edfikasi, yang merupakan akronim dari: edukasi, diseminasi informasi/inovasi, fasilitasi, konsultasi, supervisi, pemantauan dan evaluasi, yaitu:

1. Edukasi, yaitu untuk memfasilitasi proses belajar yang dilakukan oleh para penerima manfaat penyuluh (beneficiaries) dan/atau (stakeholders) pembangunan yang lainnya. Seperti telah dikemukakan, meskipun edukasi berarti pendidikan, tetapi proses pendidikan tidak boleh menggurui apalagi memaksakan kehendak (indoktrinasi, agitasi), melainkan harus benar-benar berlangsung sebagai proses belajar bersama yang partisipatif dan dialogis.

2. Diseminasi informasi/inovasi, yaitu penyebarluasan informasi/inovasi dari sumber informasi dan/atau penggunanya. Tentang hal ini, seringkali kegiatan penyuluh hanya terpaku untuk lebih mengutamakan penyebaran informasi/inovasi dari pihak luar. Tetapi, dalam proses pembangunan, informasi dari "dalam" seringkali justru lebih penting, utamanya yang terkait dengan kebutuhan-kebutuhan masyarakat, pengambilan keputusan kebijakan, dan/atau pemecahan masalah yang segera memerlukan penanganan.

3. Fasilitasi, atau pendampingan, yang lebih bersifat melayani kebutuhan- 
kebutuhan yang dirasakan oleh kliennya. Fungsi fasilitasi tidak harus selalu dapat mengambil keputusan, memecahkan masalah, dan/atau memenuhi sendiri kebutuhan-kebutuhan klien, tetapi seringkali justru hanya sebagai penengah/mediator.

4. Konsultasi, yang tidak jauh berbeda dengan fasilitasi, yaitu membantu memecahkan masalah atau sekadar memberikan alternatif-alternatif pemecahan masalah. Dalam melaksanakan peran konsultasi, penting untuk memberikan rujukan kepada pihak lain yang "lebih mampu" dan/atau lebih kompeten untuk menanganinya. Dalam melaksanakan fungsi konsultasi, penyuluh tidak boleh hanya "menunggu" tetapi harus aktif mendatangi kliennya.

5. Supervisi, atau pembinaan. Dalam praktek, supervisi seringkali disalahartikan sebagai kegiatan "pengawasan" atau "pemeriksaan". Tetapi sebenarnya adalah, lebih banyak pada upaya untuk bersama-sama klien melakukan penilaian (self assesment), untuk kemudian memberikan saran alternatif perbaikan atau pemecahan masalah yang dihadapi.

6. Pemantauan, yaitu kegiatan evaluasi yang dilakukan selama proses kegiatan sedang berlangsung. Karena itu, pemantauan tidak jauh berbeda dengan supervisi. Bedanya adalah, kegiatan pemantauan lebih menonjolkan peran penilaian, sedang supervisi lebih menonjolkan peran“upaya perbaikan".

7. Evaluasi, yaitu kegiatan pengukuran dan penilaian yang dapat dilakukan pada sebelum (formatif), selama (on-going, pemantauan) dan setelah kegiatan selesai dilakukan (sumatif, ex-post). Meskipun demikian, evaluasi seringkali hanya dilakukan setelah kegiatan selesai,untuk melihat proses hasil kegiatan (output), dan dampak (outcome) kegiatan, yang menyangkut kinerja (performance) baik teknis maupun finansialnya. dalam pemberdayaan petani akan dideskripsikan berdasarkan persepsi petani karet di Desa Lada Mandala Jaya. Persepsi adalah pengalaman tentang objek, peristiwa, atau hubungan-hubungan yang diperoleh dengan menyimpulkan informasi dan menafsirkan pesan oleh proses pengindrasaan, yaitu proses diterimanya stimulus oleh alat indra, kemudian individu ada perhatian, lalu diteruskan ke otak, dan baru kemudian individu ada perhatian, lalu diteruskan ke otak, dan baru kemudian individu menyadari tentang sesuatu yang dinamakan persepsi. Dengan persepsi individu menyadari dapat mengerti tentang keadaan lingkungan yang ada disekitar maupun tentang hal yang ada dalam diri individu yang bersangkutan. Persepsi adalah proses pengorganisasian, penginterpretasian terhadap rangsangan yang diterima oleh organisme atau individu sehingga merupakan sesuatu yang berarti dan merupakan aktivitas yang terpadu dalam diri individu (Sunaryo, 2004). Persepsi juga merupakan pandangan orang tentang kenyataan, persepsi merupakan proses yang kompleks yang dilakukan orang untuk memilih, mengatur dan memberi makna pada kenyataan yang dijumpai disekelilingnya, persepsi sendiri dipengaruhi pengalaman, pendidikan dan kebudayaan (Hardjana, 2007).

Skala Likert digunakan untuk mengukur sikap, pendapat, dan persepsi petani karet terhadap peran penyuluh pertanian. Dalam penelitian seperti ini telah ditetapkan secara spesifik oleh peneliti sebagai variabel penelitian. Menurut Sugiyono (2014) bahwa jawaban untuk setiap butir instrumen yang menggunakan skala likert mempunyai gradasi dari sangat positif sampai sangat negatif. Penggunaan skala likert ada tiga alternatif model, yaitu respon skala tiga, respon skala empat dan respon skala lima. Skala disusun dalam bentuk suatu pernyataan yang diikuti oleh pilihan respon yang menunjukan tingkatan. 
Dalam penggunaan respon, respon skala tiga adalah variabilitas respon terlalu terbatas sehingga kurang mampu mengungkap secara maksimal perbedaan sikap responden. Pilihan respon skala empat mempunyai variabilitas respon cukup baik atau lebih lengkap dibandingkan skala tiga sehingga mampu mengungkap lebih maksimal perbedaan sikap respon. Pilihan respon skala lima mempunyai variabilitas yang lebih baik atau lebih lengkap dibandingkan skala empat dan skala tiga sehingga mampu mengungkap lebih maksimal perbedaan sikap responden. Pembuatan instrumen juga dapat dibuat dalam bentuk check list dan juga dalam bentuk pilihan ganda.

Menurut Riduwan (2007) dengan menggunakan skala Likert, maka variabel yang akan diukur dijabarkan menjadi dimensi, dimensi dijabarkan menjadi subvariabel yang kemudian sub-variabel dijabarkan lagi menjadi indikator-indikator yang dapat diukur. Akhirnya indikatorindikator yang terukur ini dapat dijadikan titik tolak untuk membuat item instrumen yang berupa pertanyaan atau pernyataan yang perlu ditanggapi responden.

\section{Tinjauan Terhadap Penelitian Terdahulu}

Berdasarkan penelitian yang dilakukan oleh Oktaviani (2012) tentang persepsi petani terhadap kinerja penyuluh diketahui bahwa (1) kebanyakan dari masyarakat diKelurahan Banturung merupakan masyarakat yang memiliki pekerjaan utama sebagai petani, beberapa jenis pertanian yang diusahakan yaitu tanaman palawija, tanaman hortikultura, tanaman perkebunan bahkan beternak dan pembudidayaan ikan, (2) permasalahan yang dihadapi oleh petani adalah masih kurangnya modal petani dalam pelaksanaan pembudidayaan, lahan milik petani yang tidak besar, dan keadaan cuaca yang tidak jelas, dan (3) persepsi petani terhadap kinerja penyuluh memiliki skor rata-rata penilaian kinerja adalah sebesar $71,86 \%$, yang berarti kinerja penyuluh di Kelurahan Banturung masuk dalam ketegori baik. Penelitian yang bersesuaian mengenai persepsi dan peran penyuluh juga dilakukan oleh Najib dan Rahwita (2010) menggunakan skala Likert dan pemilihan responden menggunakan Proportionate Stratified Random Sampling, Meksy, dkk (2016) juga menggunakan skala Likert di mana untuk mengukur persepsi petani terhadap peran penyuluh adalah metode self report, dan Hutasoit, dkk (2015) menganalisis persepsi dengan mengukur enam aspek peremajaan kelapa sawit.

\section{METODE PENELITIAN}

Penelitian ini dilaksanakan di Desa Lada Mandala Jaya Kecamatan Pangkalan Lada Kabupaten Kotawaringin Barat. Data yang dikumpulkan yaitu data primer dan sekunder. Data primer merupakan data yang didapat dari hasil wawancara dan pengisian kuesioner oleh responden. Data sekunder diperoleh dari instansi terkait terutama dari Kantor Penyuluhan Pertanian dan Ketahanan Pangan Kabupaten Kotawaringin Barat serta Balai Penyuluhan Pertanian Kecamatan Pangkalan Lada. Petani karet responden dipilih secara proporsional pada tingkat Rukun Warga (RW) sebanyak $31 \mathrm{KK}$.

Penyelenggaraan penyuluhan pertanian dideskripsikan dengan cara memberi gambaran berupa kalimat ataupun tabel yang disertai interpretasinya. Selanjutnya persepsi petani terhadap peran penyuluhan pertanian menggunakan Skala Likert di mana variabel, sub variabel, dan indikatornya sebagaimana dapat dilihat pada Tabel 3. 
Tabel 3. Variabel Pengukur Persepsi Petani Karet di Wilayah Studi Terhadap Peran Penyuluh Pertanian

\begin{tabular}{|c|c|c|}
\hline Variabel & Sub Variabel & Indikator \\
\hline \multirow{6}{*}{$\begin{array}{l}\text { Peran } \\
\text { Penyuluh } \\
\text { Pertanian }\end{array}$} & Edukasi & $\begin{array}{l}\text { a. Relevansi materi dengan kebutuhan } \\
\text { b. Peningkatan pengetahuan petani } \\
\text { c. Waktu bimbingan dan kunjungan }\end{array}$ \\
\hline & Diseminasi & a. Penyebaran informasi kepetani \\
\hline & Fasilitasi & $\begin{array}{l}\text { a. Memfasilitasi keluhan petani } \\
\text { b. Mewujudkan kemitraan petani dan pengusaha }\end{array}$ \\
\hline & Konsultasi & $\begin{array}{l}\text { a. memecahkan permasalahan bersama dan Waktu } \\
\text { koonsultasi }\end{array}$ \\
\hline & Supervisi & $\begin{array}{l}\text { a. Pembinaan kemampuan teknik berusaha tani karet } \\
\text { b. Pembinaan pemasaran } \\
\text { c. Pembinaan pemanfaatan SDA dan SDM }\end{array}$ \\
\hline & $\begin{array}{l}\text { Monitoring dan } \\
\text { Evaluasi }\end{array}$ & $\begin{array}{l}\text { a. Monitoring dan evaluasi terhadap usaha tani karet } \\
\text { yang telah dijalankan }\end{array}$ \\
\hline
\end{tabular}

Sumber: Mardikanto, 2010.

Setelah diketahui variabel, subvariabel dan indikatornya maka dibuat item/butir pernyataan yang dapat dilihat pada bagian lampiran. Untuk mengetahui penilaian pada pengukuran peran penyuluh di Desa Lada Mandala Jaya, Kecamatan Pangkalan Lada, berdasarkan persepsi petani pada masing-masing peran penyuluh yaitu dengan menentukan jarak interval atau rentang kelas agar dapat diketahui nilai dari setiap ketegori bobot, bobot yang digunakan dalam penelitian ini adalah dengan menggunakan respon skala lima, sebagai berikut:

- Sangat Berperan = Bobot 5

- Kurang Berperan = Bobot 2

- Berperan = Bobot 4

- Cukup Berperan = Bobot 3

- Tidak Berperan $=$ Bobot 1

Sebelum tahapan perhitungan skor persepsi untuk pengkategorian persepsi petani terhadap peran penyuluh, maka dilakukan pengujian instrumen setiap item atau butir-butir pernyataan pada setiap indikator yang telah diajukan kepada responden agar dapat diketahui apakah instrumen yang digunakan apakah instrumen yang digunakan telah tepat dan dapat dipercaya untuk mengukur persepsi petani, maka dari itu maka dilakukan uji validitas dan uji reliabilitas. Di dalam pengujian validitas dan reliabilitas maka digunakan alat bantu analisis yaitu program SPSS 23 (Statistical Package for Social Sciences) dan berdasarkan hasil data dari persepsi pada setiap item atau butir pernyataan yang diajukan kepada seluruh responden pada masing-masing peran penyuluhan maka akan diketahui hasil validitas pada setiap item atau butir pernyataan dan reliabelnya instrumen yang digunakan didalam penelitian ini.

\section{HASIL DAN PEMBAHASAN}

Persepsi petani dapat diartikan sebagai suatu tanggapan, pemikiran dan pandangan petani terhadap program penyuluhan. Penyuluhan pertanian merupakan salah satu sumber informasi bagi petani dalam meningkatkan produktifitas petani. Kegiatan penyuluhan dapat berjalan apabila adanya petani yang mendukung sehingga tujuan dengan diadakannya penyuluhan tersebut dapat tersampaikan dan terealisasi pada petani di Desa Lada Mandala Jaya.

Keberhasilan pembangunan pertanian salah satunya ditentukan oleh dukungan dan peran aktif dari penyuluh yang membina wilayah pertanian, Desa Lada Mandala Jaya merupakan salah satu daerah yang tidak lepas dari peran seorang penyuluh dalam pembangunan 
pertaniannya. Penilaian yang dilakukan untuk melihat persepsi petani terhadap peran penyuluhan perkebunan karet menggunakan beberapa variabel yakni peran penyuluh pertanian sebagai edukasi, diseminasi, fasilitasi, supervisi, dan peran penyuluh pertanian sebagai monitoring dan evaluasi. Petani pada tanaman karet di Desa Lada Mandala Jaya merupakan salah satu sasaran dari penyuluh dan yang merasakan manfaat langsung dari kegiatan penyuluhan, dan dengan demikian peneliti menggunakan 31 orang petani karet untuk mengetahui persentase persepsi petani terhadap peran penyuluh. Untuk mengetahui persentase jawaban petani dapat dilihat pada Tabel 4 .

Tabel 4. Persentase Persepsi Petani Terhadap Peran Penyuluh di Wilayah Studi

\begin{tabular}{lrc}
\hline \multicolumn{1}{c}{ Kriteria } & Responden & Persentase (\%) \\
\hline Sangat berperan ( SB) & 0 & 0 \\
Berperan (B) & 7 & 23 \\
Cukup Berperan(CB) & 24 & 77 \\
Kurang Berperan (KB) & 0 & 0 \\
TidakBerperan (TB) & 0 & 0 \\
\hline \multicolumn{1}{c}{ Jumlah } & 31 & 100 \\
\hline
\end{tabular}

Sumber: Data Primer yang diolah, Tahun 2018

Berdasarkan Tabel 4, menunjukkan bahwa persepsi sebagian besar petani (77\%) menyatakan bahwa penyuluh "cukup berperan", sisanya (23\%) petani menyatakan bahwa penyuluh sudah "berperan" dalam tugas dan fungsinya.

Kemudian dengan menggunakan analisis skoring (skala Likert) pada ke enam sub variabel peran penyuluh di Desa Lada Mandala Jaya, Kecamatan Pangkalan Lada, Kabupaten Kotawaringin Barat yaitu, peran penyuluh sebagai edukasi, diseminasi, fasilitasi, konsultasi, supervisi, monitoring, evaluasi, dapat diketahui persepsi petani terhadap peran penyuluh, sebagaimana dapat dilihat pada Tabel 5.

Tabel 5. Rekapitulasi Skor Persepsi Petani di Wilayah Studi terhadap Peran Penyuluh Pertanian Secara Keseluruhan

\begin{tabular}{|c|c|c|c|c|c|}
\hline \multirow{2}{*}{ No. } & \multirow{2}{*}{ Variabel } & \multicolumn{4}{|c|}{ Analisis Skoring } \\
\hline & & Item & Skor & Rerata & Kategori \\
\hline 1. & Edukasi & 14 & 1.605 & 3,69 & Berperan \\
\hline 2. & Diseminasi & 3 & 318 & 3,41 & Berperan \\
\hline 3. & Fasilitasi & 4 & 278 & 2,24 & Kurang Berperan \\
\hline 4. & Konsultasi & 3 & 293 & 3,15 & Cukup Berperan \\
\hline 5. & Supervisi & 9 & 726 & 2,60 & Kurang Berperan \\
\hline 6. & Monitoring dan Evaluasi & 2 & 162 & 2,61 & Cukup Berperan \\
\hline & Total & 35 & 3.382 & 3,11 & Cukup Berperan \\
\hline
\end{tabular}

Sumber: Data primer yang diolah, Tahun 2018

Berdasarkan uraian Tabel 5, dapat diketahui bahwa peran penyuluhan dalam kegiatan usahatani karet di Desa Lada Mandala Jaya Kecamatan Pangkalan Lada Kabupaten Kotawaringin Barat yang dilihat dari sub variabel edukasi, diseminasi, fasilitasi, konsultasi, supervisi serta monitoring dan evaluasi persepsi petani secara keseluruhan mendapat nilai skor 3,11 yaitu "Cukup Berperan".

Berdasarkan Tabel 5 di atas dapat pula diketahui bahwa terdapat beberapa 
sub variabel dan indikator peran penyuluh yang sudah "berperan" dilakukan oleh penyuluh kepada petani karet yang ada di Desa Lada Mandala Jaya. Sub variabel edukasi, dengan indikator relevansi materi dengan kebutuhan petani dalam menjalankan perannya untuk mengajarkan atau mendidik petani karet dengan baik yang dapat meningkatkan pengetahuan dan keterampilan petani dalam melakukan usahatani karet, serta penyuluh dalam memberikan bimbingan atau kunjungan kepada petani baik itu memperhatikan waktu petani saat melakukan penyuluhan, meluangkan waktu untuk berkunjung kepada petani baik di ladang maupun di rumah petani. Selain itu berperannya diseminasi informasi, dimana membantu dalam menyampaikan pemahaman tentang teknologi pertanian terbaru tentang budidaya karet, serta menyampaikan info harga sarana produksi kepada petani sehingga petani merasa peran penyuluhan sebagai edukasi dan diseminasi informasi berperan dalam pelaksanaannya. Selain itu, penyuluh memfasilitasi pengembangan motivasi/minat untuk berusahatani karet, penyuluh memfasilitasi keluhan petani dalam bentuk sarana produksi seperti bibib karet unggul dan teknologi pertanian seperti mangkok, sabit, tali pengikat. Untuk sub variabel dan indikator yang "cukup berperan" bahwasanya penyuluh memberikan alternatif pemecahan masalah yang dihadapi petani serta penyuluh juga menerima konsultasi dari petani baik itu secara langsung maupun tidak langsung, melakukan pembinaan kemampuan teknik berusahatani karet baik itu produksi maupun produktivitas, dapat menunjang keberhasilan usahatani karet sehingga petani merasa peran penyuluhan sebagai konsultasi cukup berperan. Penilaian persepsi petani terhadap pentingnya peran penyuluhan sebagai monitoring dan evaluasi dilihat petani bahwasanya penyuluh cukup berperan melakukan monitoring dan evaluasi dalam melihat perkembangan usahatani karet yang dijalankan petani hasil kegiatan
penyuluhan.

Akan tetapi ada beberapa subvariabel yang "tidak berperan" menurut persepsi petani dimana kurang maksimalnya sub variabel peran penyuluh dalam membantu petani mempromosikan hasil produksi karet, mewujudkan kemitraan dengan pengusaha, memfasilitasi hasil pemasaran usahatani karet. sehingga petani merasa penyuluhan tidak berperan di beberapa sub variabel tertentu terhadap kegiatan penyuluhan. Penyuluh sangat diharapkan petani untuk menjalin kerjasama yang baik dan meningkatkan hal-hal yang belum optimal sehingga petani tidak tergantung dengan tengkulak yang ada di Desa Lada Mandala Jaya, Kecamatan Pangkalan Lada, Kabupaten Kotawaringin Barat.

\section{KESIMPULAN DAN SARAN}

\section{Kesimpulan}

Berdasarkan hasil sub variabel peran penyuluh maka hasil persepsi petani untuk peran penyuluh di nilai berada pada kategori "Cukup Berperan" dengan ratarata secara keseluruhan 3,11. Persepsi petani terhadap peran penyuluh pertanian di Desa Lada Mandala Jaya Kecamatan Pangkalan Lada dapat dikategorikan sebagai (a). "Berperan" (rerata = 3,69) untuk sub variabel Edukasi, (b). "Berperan" (rerata = 3,41) untuk sub variabel Diseminasi, (c). "Kurang Berperan" (rerata $=2,24$ ) untuk sub variabel Fasilitasi, (d). "Cukup Berperan" (rerata $=3,15)$ sebagai konsultan, (e). "Kurang Berperan" (rerata $=2,60$ ) sebagai Supervisor, (f). "Cukup Berperan" (rerata $=2,61$ ) dalam penyelenggaraan Monitoring dan Evaluasi.

\section{Saran}

Berdasarkan kesimpulan di atas, maka disarankan kepada penyuluh agar dapat mengoptimalkan peran penyuluh terutama dalam memfasilitasi dan 
melakukan supervisi kepada petani dalam pembangunan usaha perkebunan karet.

\section{DAFTAR PUSTAKA}

Anonim. (2006). Undang-Undang Nomor 16 Tahun 2006. Sistem Penyuluhan Pertanian, Perikanan dan Kehutanan. Jakarta.

Antara Kalteng. (2014). Kalteng Kekurangan 934 Penyuluh Pertanian. http://www.antarakalteng.com/img/ logo_antara_news.gif. Diakses tanggal 25 April 2018.

Hutasoit, F. R., S. Hutabarat, \& D. Muwardi. (2015). Analisis Persepsi Petani Kelapa Sawit Swadaya Bersertifikasi RSPO Dalam Menghadapi Kegiatan Peremajaan Perkebunan Kelapa Sawit di Kecamatan Ukui Kabupaten Pelalawan.

Hardjana, A. M. (2007). Komunikasi Intrapersonal dan Interpersonal. Yogyakarta: Penerbit Kanisius.

Kartasapoetra, A. G. (1994). Teknologi Pertanian. Jakarta: Bumi Aksara.

Mardikanto. (2010). Konsep Pemberdayaan Masyarakat. Surakarta: Penerbit TS.

Najib, M., dan H. Rahwita. (2010). Penyuluh Pertanian Dalam Pengembangan Kelompok Tani di Desa Bukit Raya Kecamatan Tenggarong Seberang Kabupaten Kutai Kartanegara. Universitas Mulawarman.

Meksy V., G. Timbulus, M. L. Sondakh, \& GA. J. Rumagit. (2016). Persepsi Petani Terhadap Peran Penyuluh Pertanian di Desa Rasi Kecamatan Ratahan Kabupaten Minahasa Tenggara.

Oktaviani. (2012). Persepsi Petani Terhadap Kinerja Penyuluh Pertanian di Kelurahan Banturung Kecamatan Bukit Batu Palangka Raya. Skripsi. Universitas Palangka Raya.
Riduwan, 2015. Skala Pengukuran Variabel-Variabel Penelitian. Bandung: Penerbit Alfabeta.

Samsudin U. (1987). Dasar-Dasar Penyuluhan dan Moderenisasi Pertanian. Bandung: Percetakan Binacipta.

Sugiyono. (2014). Metode Penelitian Kuantitatif Kualitatif dan R \& D. Bandung: Penerbit Alfabeta.

Sunaryo. (2004). Psikologi untuk Keperawatan. Jakarta: Penerbit Buku Kedokteran EGC. 